\title{
Treatment of cutaneous angiosarcoma of the scalp and face in Chinese patients: local experience at a regional hospital in Hong Kong
}

\author{
TL Chow *, Wilson WY Kwan, CK Kwan
}

\section{A B S T R A C T}

Introduction: Angiosarcoma is a rare aggressive sarcoma that occurs mostly in the skin of the head and neck in the elderly population. The optimal management is dubious and most studies are from Caucasian populations. We aimed to examine the treatment and outcome of this disease in Chinese patients.

Methods: Data of patients with histopathologically verified cutaneous angiosarcoma of the head and neck during December 1997 to September 2016 were retrieved from our hospital cancer registry. The demographic data, clinicopathological information, modality of treatment, and outcomes were reviewed.

Results: During the study period, 17 Chinese patients were treated. Their median age was 81 years. The tumours were present in the scalp only $(n=11)$, face only $(n=4)$, or both scalp and face $(n=2)$. Only two patients had distant metastases. The modalities of treatment were surgery $(n=6)$, surgery and adjuvant radiotherapy $(n=1)$, palliative radiotherapy $(n=5)$, or palliative chemotherapy $(n=3)$. The remaining two patients refused any treatment initially. Of the seven

This article was published on 12 Jan 2018 at www.hkmj.org. patients treated surgically, there were four local and

was 7.5 months. Overall, 16 patients had died; causes of death were disease-related in 12 whereas four other patients died of inter-current illnesses. One patient was still living with the disease. The median overall survival was 11.1 months and the longest overall survival was 42 months.

Conclusion: The outcome of angiosarcoma in our series is poor. A high index of suspicion is mandatory for prompt diagnosis. Adjuvant radiotherapy is recommended following surgery. The benefit and role of systemic treatment in various combinations with surgery or radiotherapy require further study.

\section{Hong Kong Med J 2018;24:25-31 \\ DOI: 10.12809/hkmj176813}

\begin{abstract}
1 TL Chow *, FRCS (Edin), FHKAM (Surgery)
WWY Kwan, FRCS (Edin), FHKAM (Surgery)

${ }^{2}$ CK Kwan, FRCR, FHKAM (Radiology)
\end{abstract}

Head and Neck Division, Department of Surgery

2 Department of Oncology

United Christian Hospital, Kwun Tong, Hong Kong

* Corresponding author: chowtl@ha.org.hk

New knowledge added by this study

Reports of angiosarcoma of the scalp and face in the Chinese population are limited. Patient survival in this local study was worse than that of other studies.

- Literature review in this study supports the use of adjuvant radiotherapy to improve angiosarcoma control.

Implications for clinical practice or policy

- An aggressive but not too radical surgery for head and neck cutaneous lesions is advocated.

- Combination therapy (surgery, radiotherapy, and systemic treatment) in various combinations should be considered.

\section{Introduction}

Angiosarcoma is a rare form of sarcoma of vascular origin. It is notorious for its aggressive and relentless progression with frequent local recurrence and distant metastasis. ${ }^{1}$ Owing to its scarcity and innocuous appearance at an early stage mimicking an ordinary bruise or benign haemangioma, correct diagnosis is often delayed for several months. This problem is compounded further because most patients with angiosarcoma are elderly with frailty and co-morbidity, and prognosis after surgery as the definitive therapy is gloomy. The 5-year overall survival (OS) has been variously reported as $24 \%$ to $35 \%{ }^{1,2}$ When radiotherapy (RT) is given as the main treatment, median survival is only 8 months. ${ }^{3}$

Almost half (43\%) of angiosarcomas originate from the skin of the head and neck. ${ }^{1,2}$ Compared with truncal and extremity angiosarcoma, the prognosis of cutaneous angiosarcoma (CAS) of the head and neck is even worse. Perez et $\mathrm{al}^{2}$ indicated a greater need for flap or graft reconstruction after tumour extirpation for head and neck CAS (HNCAS), a 


\section{頭皮面部皮膚血管肉瘤華籍患者的治療：香港一 所分區醫院的經驗 \\ 周譚連、關偉賢、關仲江}

引言：血管肉瘤是一種罕見具侵襲性的肉瘤。罹患此腫瘤的病人以老 年人居多, 大多於頭部和頸部的皮膚上。此病尚未有公認的最佳治療 方案, 而大部分研究均集中在白種人口。本文報告患有此病的華籍患 者的治療方式和結果。

方法：我們從本院的癌症登記處搜集1997年12月至2016年9月期間， 經組織病理學證實患有頭頸部皮膚血管肉瘤患者的資料。回顧其人口 特徵、臨床病理學資料、治療方法和結果。

結果：研究期間共有 17 名華籍患者接受治療, 他們年齡中位數為 81 歲。有 11 例患者的腫瘤僅在頭皮上, 4 例僅在面部, 2 例在頭皮和面 部。只有兩名患者有遠處轉移。治療方式分為手術6例, 手術及輔助 放療 1 例, 緩解放療 5 例, 以及緩解化療 3 例。其餘兩名患者最初拒絕 任何治療。接受手術治療的 7 名患者中, 有4例原位復發和 2 例淋巴引 流區復發。復發時間中位數為 7.5 個月。共有 16 名病人死亡, 當中 12 例與血管肉瘤有關, 另有4例因其他疾病致死。一名患者與癌共存, 帶病延年。總生存期中位數為 11.1 個月, 最長整體生存期為42個月

結論：本研究發現血管肉瘤病的預後欠佳。醫生應對此病保持高度警 惕, 以作出及時的診斷。我們建議病人手術後接受輔助放療。全身性 治療併合手術或放療各種組合的優點和作用須作進一步的研究。 positive resection margin in 50\%, and 5-year OS of $21.5 \%$. Surgery was conventionally regarded as the mainstay of therapy for HNCAS. Because of the poor results and frequent margin involvement (78\%), ${ }^{4}$ a multidisciplinary approach with adjuvant RT has been advocated.

To the best of our knowledge, most articles about HNCAS derived from a Caucasian population. We are not aware of any reported series from ethnic Chinese populations. We therefore conducted this retrospective study of HNCAS in the Chinese patients managed in our hospital over the past two decades. Demographic data, clinicopathological information, modality of treatment, and outcomes were reviewed. The latest approaches to the treatment of this devastating disease are also discussed.

\section{Methods}

Records of patients with histopathologically verified HNCAS from December 1997 to September 2016 were captured from the head and neck cancer registry of our department. Only Chinese patients were recruited. Patient data were prospectively collected and regularly updated in the registry.

Tumours were classified as a unifocal/localised versus multifocal/diffuse form. Unifocal/localised tumour was characterised by a discrete lesion without macroscopic satellitosis; it was considered operable and potentially curable. If gross satellite lesions were present or the main tumour was too extensive to be removed surgically, it was regarded as a multifocal/diffuse tumour that was probably incurable. Superficial tumours were those confined to the skin and subcutaneous tissue. Conversely, deep tumours were defined as transgression beyond the subcutaneous layer, for example encroaching on the underlying muscle or bone.

If the tumour was resectable, a wide excision with at least a $3-\mathrm{cm}$ margin was performed. The defects were reconstructed by local scalp flap/ skin graft (scalp primary) or submental flap (face primary). ${ }^{5}$ Neck dissection was performed only in the presence of clinical or radiological evidence of nodal spread. Adjuvant RT was not routinely administered. When disease was deemed inoperable or the patient was unfit for surgery, palliative RT or chemotherapy would be considered.

The OS was calculated from the date of diagnosis to patient death or last follow-up, and is expressed in Kaplan-Meier curve. The data were computed using the SPSS (Windows version 20.0; IBM Corp, Armonk [NY], United States). The principles outlined in the 2013 version of the Declaration of Helsinki have been followed.

\section{Results}

A total of 17 patients with HNCAS were identified and managed in our institution from December 1997 to September 2016. Their demographic and clinicopathological information are shown in Table 1. In brief, males predominated and there were only two female patients. Their median age was 81 years (range, 67-92 years). Only one patient had a history of whole-scalp RT for a lateral scalp angiosarcoma more than 10 years ago in another institution. He had a new angiosarcoma on the opposite side of his scalp that was treated in our centre as a second primary angiosarcoma induced by past RT. The median duration from onset of presentation to diagnosis was 4 months (range, 2-33 months).

Patients presented with protean symptoms: bleeding $(n=7)$, pain $(n=4)$, nodule $(n=3)$, ulceration $(n=2)$, pigmentation $(n=2)$, pruritus $(n=1)$, and localised oedema $(n=1)$. One patient presented with an asymptomatic purplish macule but no other symptoms.

The tumours were present in the scalp only $(n=11)$, face only $(n=4)$, or both scalp and face $(n=2)$. No patient had neck CAS. Ten patients had a localised/unifocal tumour. Seven patients were inflicted by multiple/diffuse lesions that were considered inoperable and treated with palliative intent in four. Of the three remaining patients with multiple/diffuse lesions, the tumours were still amenable to potentially curative surgery although two (cases 7 and 15) declined any treatment 
TABLE I. Demographics, clinicopathological characteristics, and outcome

\begin{tabular}{|c|c|c|c|c|c|c|c|c|c|c|c|}
\hline \multirow{2}{*}{$\begin{array}{l}\text { Case } \\
\text { No. }\end{array}$} & \multirow[t]{2}{*}{ Sex } & \multirow{2}{*}{$\begin{array}{c}\text { Age } \\
\text { (years) }\end{array}$} & \multirow{2}{*}{$\begin{array}{c}\text { Previous } \\
\text { radiotherapy }\end{array}$} & \multirow[t]{2}{*}{ Initial diagnosis } & \multirow[t]{2}{*}{ Location* } & \multirow[t]{2}{*}{ Extent } & \multirow{2}{*}{$\begin{array}{c}\text { Deep } \\
\text { invasion }\end{array}$} & \multirow{2}{*}{$\begin{array}{l}\text { Dx delay } \\
\text { (months) }\end{array}$} & \multicolumn{3}{|c|}{ Stage† } \\
\hline & & & & & & & & & Tumour & Node & Metastasis \\
\hline 1 & Male & 88 & No & Bruise & $\mathrm{F}+\mathrm{S}$ & Diffuse & Yes & 3 & $\mathrm{~T} 2$ & N1 & MO \\
\hline 2 & Female & 77 & No & Cellulitis & $\mathrm{F}$ & Diffuse & No & 2 & $\mathrm{~T} 2$ & $\mathrm{~N} 1$ & M1 \\
\hline 3 & Male & 86 & No & Parotid swelling & $\mathrm{F}$ & Diffuse & No & 3 & T2 & No & M1 \\
\hline 4 & Male & 85 & No & Haemangioma & $S$ & Localised & No & 5 & T2 & $\mathrm{N} 1$ & MO \\
\hline 5 & Male & 80 & No & Scalp ulcer & $\mathrm{S}$ & Localised & No & 6 & $\mathrm{~T} 1$ & $\mathrm{~N} 1$ & MO \\
\hline 6 & Male & 71 & No & Angiosarcoma & $S$ & Localised & No & 5 & T2 & No & MO \\
\hline 7 & Male & 90 & No & Pigmented lesion & $\mathrm{F}$ & Diffuse & No & 24 & T2 & No & MO \\
\hline 8 & Male & 70 & No & Angiosarcoma & $S$ & Localised & No & 6 & $\mathrm{~T} 1$ & No & MO \\
\hline 9 & Male & 75 & Yes & Angiosarcoma & $S$ & Localised & No & 2 & $\mathrm{~T} 1$ & No & MO \\
\hline 10 & Male & 67 & No & Haemangioma & $S$ & Diffuse & No & 4 & T2 & No & MO \\
\hline 11 & Male & 91 & No & Skin nodule & $\mathrm{F}$ & Localised & No & 2 & $\mathrm{~T} 1$ & No & MO \\
\hline 12 & Male & 81 & No & Angiosarcoma & $S$ & Localised & No & 3 & T2 & N1 $\ddagger$ & MO \\
\hline 13 & Male & 88 & No & Angiosarcoma & $S$ & Localised & No & 6 & T2 & No & MO \\
\hline 14 & Female & 83 & No & Scalp SCC & $S$ & Localised & No & 4 & $\mathrm{~T} 1$ & No & MO \\
\hline 15 & Male & 76 & No & Pigmented lesion & $S$ & Diffuse & No & 12 & $\mathrm{~T} 1$ & No & MO \\
\hline 16 & Male & 76 & No & Parotid swelling & $\mathrm{S}+\mathrm{F}$ & Diffuse & Yes & 4 & T2 & N1 & MO \\
\hline 17 & Male & 92 & No & Pigmented lesion & $S$ & Localised & No & 33 & $\mathrm{~T} 1$ & NO & MO \\
\hline
\end{tabular}

Abbreviations: $\mathrm{Dx}=$ diagnosis; $\mathrm{SCC}=$ squamous cell carcinoma

* F denotes face and $\mathrm{S}$ scalp

$+\mathrm{TI} \leq 5 \mathrm{~cm}$ and $\mathrm{T} 2>5 \mathrm{~cm}$; N0 denotes nodal spread absent and NI nodal spread present; $\mathrm{M} 0$ denotes distant metastasis absent and MI distant metastasis present

$\ddagger$ Bilateral neck metastases

initially. Deep invasion occurred in two patients. Of the 11 patients whose tumour dimension had been documented, the median diameter was $4 \mathrm{~cm}$ (range, 3-13 cm). In the other six patients in whom dimensions were not recorded, there was extensive involvement by the HNCAS.

At the time of diagnosis, the numbers of $\mathrm{T} 1$ $(\leq 5 \mathrm{~cm})$ and $\mathrm{T} 2(>5 \mathrm{~cm})$ diseases were seven and 10 , respectively. Regional nodal spread was present in six patients. Only two patients (cases 2 and 3) were found to have distant metastases: lung in one patient, and lung and spine in the other (Table 1). The modalities of therapy were surgery $(n=6)$, surgery + adjuvant RT $(n=1)$, palliative RT $(n=5)$, and palliative chemotherapy ( $n=3$; two of them also received palliative $\mathrm{RT}$ following chemotherapy). The remaining two patients (cases 7 and 15) refused any form of treatment initially (Table 2). Incorporating subsequent therapy, surgery, RT and chemotherapy were eventually offered to seven, 10 , and five patients, respectively.

Of the seven patients treated surgically, the resection margin was positive in two. Tumour recurred in six of them: four local and two regional recurrences. The median time to relapse was 7.5 months (range, 2-32 months). Overall, 16 patients had died; the causes of death were HNCAS in 12 and inter-current diseases in four (Table 2). One patient (case 15) was still living with the disease 21 months after diagnosis. The median OS was 11.1 months and the longest OS in our series was 42 months (case 6) [Fig 1].

\section{Discussion}

The oncological outcome of this study is obviously far from satisfactory when compared with a reported median survival of 13.4 to 64 months as shown in Table 3,4-12 which summarises the postulated prognosticators. Only those studies performed over the past two decades and that focused on HNCAS with more than 10 cases were included. Patient age, tumour size, tumour differentiation, deep invasion, and margin status showed conflicting results. Of note, RT was the most promising and consistent prognosticator; only one study showed an adverse effect on survival. ${ }^{10}$ The disparity might well be due to selection bias for RT in a retrospective studymore advanced disease tends to receive adjuvant RT. The evidence lends credence to adjuvant RT for HNCAS. The suboptimal outcome in our study is multifactorial: detainment of diagnosis, 
TABLE 2. Treatment and outcome

\begin{tabular}{|c|c|c|c|c|}
\hline $\begin{array}{l}\text { Case } \\
\text { No. }\end{array}$ & $\begin{array}{l}\text { Resection } \\
\text { margin }\end{array}$ & Treatment & $\begin{array}{l}\text { Follow-up } \\
\text { duration } \\
\text { (months) }\end{array}$ & Outcome \\
\hline 1 & Not applicable & Palliative chemotherapy & 3 & Died of other illness* \\
\hline 2 & Not applicable & Palliative radiotherapy & 2 & Died of other illness $†$ \\
\hline 3 & Not applicable & Palliative radiotherapy & 2 & Died of disease \\
\hline 4 & Not applicable & Palliative radiotherapy & 18 & Lung metastasis with chemotherapy; died of disease \\
\hline 5 & Positive & Surgery but refused neck dissection & 9 & Died of other illness $\ddagger$ \\
\hline 6 & Not applicable & Palliative chemotherapy + radiotherapy & 42 & Died of disease \\
\hline 7 & Not applicable & Refused any treatment & 13 & Died of disease \\
\hline 8 & Positive & Surgery + radiotherapy & 17 & Local relapse with palliative chemotherapy; died of disease \\
\hline 9 & Negative & Surgery & 18 & Local relapse with supportive treatment; died of disease \\
\hline 10 & Negative & Surgery & 7 & Nodal relapse with supportive treatment; died of disease \\
\hline 11 & Negative & Surgery & 6 & $\begin{array}{l}\text { Local relapse, complete response to radiotherapy; died of } \\
\text { other illness } \S\end{array}$ \\
\hline 12 & Not applicable & Palliative radiotherapy & 10 & Died of disease \\
\hline 13 & Negative & Surgery & 39 & Local relapse with palliative radiotherapy; died of disease \\
\hline 14 & Negative & Surgery & 6 & $\begin{array}{l}\text { Nodal relapse with surgery done; lung metastases later; } \\
\text { died of disease }\end{array}$ \\
\hline 15 & Not applicable & Refused any treatment & 21 & Palliative radiotherapy for bleeding; survive with disease \\
\hline 16 & Not applicable & Palliative chemotherapy + radiotherapy & 11 & Died of disease \\
\hline 17 & Not applicable & Palliative radiotherapy (refused surgery) & 13 & Died of disease \\
\hline $\begin{array}{lll}* & \text { Died } \\
+ & \text { Died } \\
+ & \text { Died } \\
\$ & \text { Knon }\end{array}$ & $\begin{array}{l}\text { of pneumoperito } \\
\text { of pneumonia an } \\
\text { in concomitant lur }\end{array}$ & $\begin{array}{l}\text { ritoneum } \\
\text { um } \\
\text { trial fibrillation } \\
\text { cancer and died of lung cancer recurrence }\end{array}$ & tually & \\
\hline
\end{tabular}

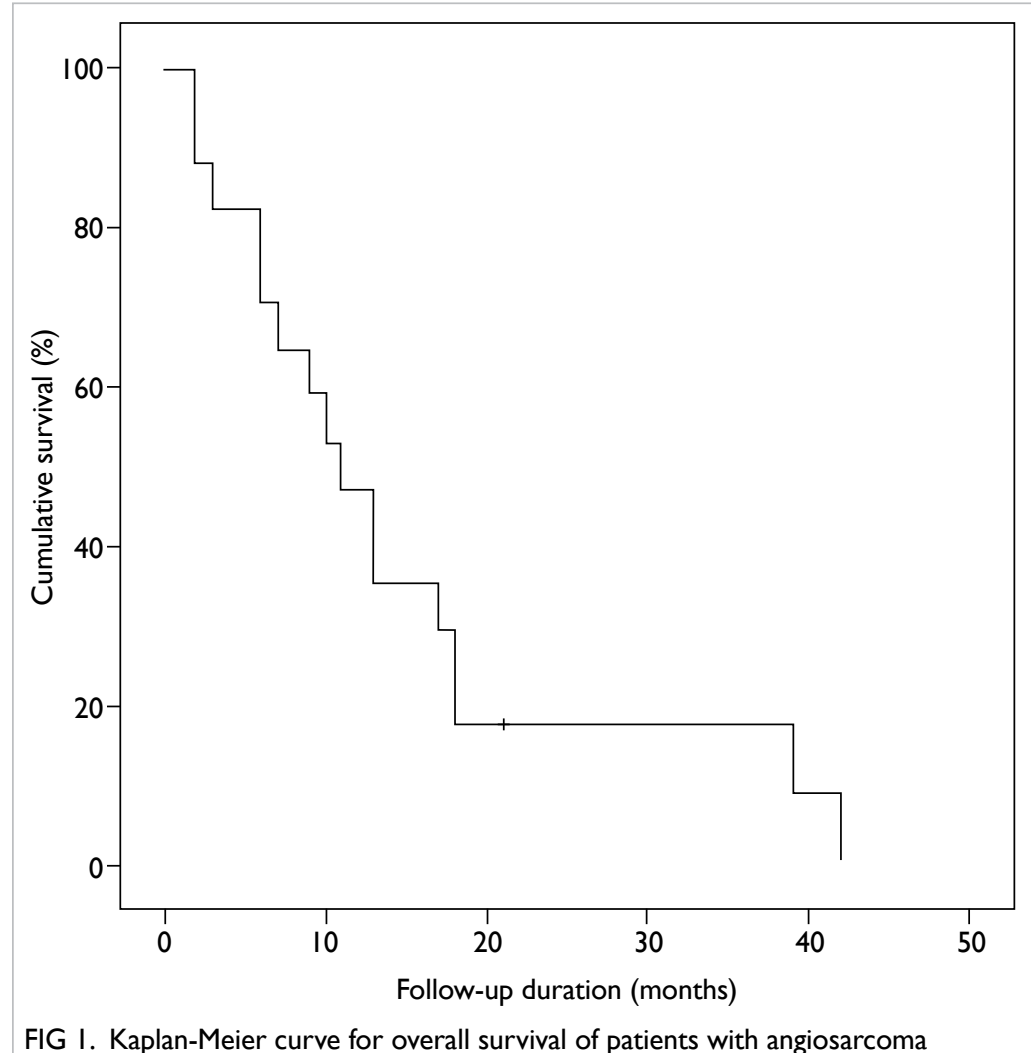

FIG I. Kaplan-Meier curve for overall survival of patients with angiosarcoma inclusion of palliative cases for survival evaluation, advanced age precluding curative treatment, and unpopular adoption of RT or chemotherapy as multimodal therapy. In this series, adjuvant RT was administered to only one patient after surgery, either because others declined RT or wound complications precluded its application.

The diagnosis of HNCAS is often late as early lesions can simulate innocent violaceous macules masquerading as benign dermatological entities (Fig 2). From our experience, the median duration was 4 months prior to diagnostic confirmation with histopathological examination. Three of our patients (cases 7, 15, and 17) had their diagnosis made more than 12 months after onset of disease. The longest delay was 33 months (case 17) and is absolutely not acceptable. Interestingly, HNCAS manifested as pigmented lesions in two patients and thereby misled clinicians in decision making. Increased awareness of this rare disease by primary care clinicians is essential to expedite patient referral. For specialists, a low threshold to biopsy of newly developed purplish skin lesions in the elderly patients is pivotal to an early diagnosis.

In our series, patients who underwent palliative therapy were included in the OS calculation and 
TABLE 3. Survival prognosticators from the literature

\begin{tabular}{|c|c|c|c|c|c|c|c|c|c|c|c|}
\hline \multirow[t]{2}{*}{ Study } & \multirow{2}{*}{$\begin{array}{c}\text { No. of } \\
\text { patients } \\
\text { (male/ } \\
\text { female) }\end{array}$} & \multirow{2}{*}{$\begin{array}{c}\text { Age } \\
\text { (years) }\end{array}$} & \multirow[t]{2}{*}{ Location } & \multirow[t]{2}{*}{ Treatment } & \multirow{2}{*}{$\begin{array}{l}\text { Survival } \\
\text { (months) }\end{array}$} & \multicolumn{6}{|c|}{ Prognosticators } \\
\hline & & & & & & Size & $\begin{array}{c}\text { Age } \\
\text { (years) }\end{array}$ & Diff & RT & DI & Margin \\
\hline $\begin{array}{l}\text { Aust et al, }{ }^{6} \\
1997\end{array}$ & $32(23 / 9)$ & $63(18-91)$ & Head and neck & $\mathrm{S}, \mathrm{S}+\mathrm{RT}, \mathrm{RT}, \mathrm{RT}+\mathrm{C}$ & $\begin{array}{l}57.6 \text { (MOS); } \\
41 \% \text { (5-year OS) }\end{array}$ & Yes $(7 \mathrm{~cm})$ & No & No & Yes & Yes & Yes \\
\hline $\begin{array}{l}\text { Pawlik et } \\
\text { al },{ }^{4} 2003\end{array}$ & $29(18 / 11)$ & $71(33-90)$ & Scalp & $\mathrm{S}+/-\mathrm{RT}$ & 28.4 (MOS) & Yes $(5 \mathrm{~cm})$ & Yes (70) & No & Yes & $\mathrm{N} / \mathrm{S}$ & No \\
\hline $\begin{array}{l}\text { Guadagnolo } \\
\text { et al, }{ }^{7} 2011\end{array}$ & $70(50 / 20)$ & $71(9-85)$ & Scalp and face & $\mathrm{S}, \mathrm{RT}, \mathrm{S}+\mathrm{RT}$ & $\begin{array}{l}41.0 \text { (MOS); } \\
43 \% \text { (5-year OS) }\end{array}$ & Yes $(5 \mathrm{~cm})$ & $N / S$ & $\mathrm{~N} / \mathrm{S}$ & Yes & $\mathrm{N} / \mathrm{S}$ & No \\
\hline $\begin{array}{l}\text { Ogawa et } \\
\mathrm{al}^{8} 2012\end{array}$ & $48(29 / 19)$ & $\mathrm{N} / \mathrm{S}$ & Scalp and face & $\begin{array}{l}\text { Heterogeneous } \\
\text { single or combined } \\
\text { modality treatment }\end{array}$ & $\begin{array}{l}13.4 \text { (MOS); } \\
4.2 \% \text { (5-year } \\
\text { OS) }\end{array}$ & No $(5 \mathrm{~cm})$ & No (80) & $\mathrm{N} / \mathrm{S}$ & Yes & $\mathrm{N} / \mathrm{S}$ & $\mathrm{N} / \mathrm{S}$ \\
\hline $\begin{array}{l}\text { Miki et al, }{ }^{9} \\
2013\end{array}$ & $17(12 / 5)$ & $73(52-88)$ & Scalp and face & $\mathrm{RT}+/-\mathrm{C}+/-\mathrm{S}$ & 26.0 (MOS) & No $(5 \mathrm{~cm})$ & No (75) & $\mathrm{N} / \mathrm{S}$ & $\begin{array}{c}\text { All patients } \\
\text { underwent } \\
\text { RT }\end{array}$ & $\mathrm{N} / \mathrm{S}$ & $\mathrm{N} / \mathrm{S}$ \\
\hline $\begin{array}{l}\text { Dettenborn } \\
\text { et al, },^{10} 2014\end{array}$ & $80(50 / 30)$ & $71.4 \pm 14.4$ & Scalp and face & $\mathrm{S}+/-\mathrm{RT}+/-\mathrm{C}$ & $\begin{array}{l}64.0 \text { (MOS); } \\
54.0 \% \text { (5-year } \\
\text { OS) }\end{array}$ & No $(5 \mathrm{~cm})$ & Yes (70) & No & $\begin{array}{l}\text { Yes (worse } \\
\text { prognosis } \\
\text { with RT) }\end{array}$ & No & Yes \\
\hline $\begin{array}{l}\text { Patel et al, }{ }^{11} \\
2015\end{array}$ & $55(39 / 16)$ & $\mathrm{N} / \mathrm{S}$ & Scalp and face & $\begin{array}{l}\text { Heterogeneous } \\
\text { single or combined } \\
\text { modality treatment }\end{array}$ & $\begin{array}{l}25.2 \text { (MOS); } \\
38 \% \text { (5-year OS) }\end{array}$ & No $(5 \mathrm{~cm})$ & Yes (70) & No & Yes & $\mathrm{N} / \mathrm{S}$ & No \\
\hline $\begin{array}{l}\text { Suzuki et } \\
\text { al, }{ }^{12} 2016\end{array}$ & $14(9 / 5)$ & 77 (67-84) & Scalp and face & $\begin{array}{l}\text { Various combined } \\
\text { modality treatment }\end{array}$ & 31 (MOS) & No $(5 \mathrm{~cm})$ & Yes (78) & $\mathrm{N} / \mathrm{S}$ & $\begin{array}{c}\text { All patients } \\
\text { underwent } \\
\text { RT }\end{array}$ & $\mathrm{N} / \mathrm{S}$ & $\mathrm{N} / \mathrm{S}$ \\
\hline
\end{tabular}

Abbreviations: $\mathrm{C}=$ chemotherapy; $\mathrm{DI}=$ deep invasion; Diff = tumour differentiation; $\mathrm{MOS}=$ median overall survival; $\mathrm{N} / \mathrm{S}=$ not studied; $O \mathrm{~S}=$ overall survival; $R T$ = radiotherapy; $S$ = surgery

* Data are shown as median (range) or mean \pm standard deviation

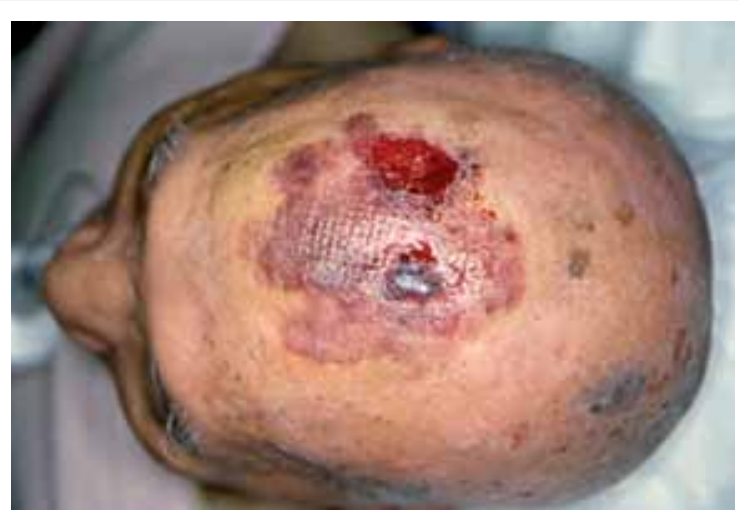

FIG 2. Angiosarcoma of the scalp can mimic benign vascular lesions

this might have partially contributed to our poor results. This was echoed by Buschmann et $\mathrm{al}^{13}$ who also included patients with palliative resection in outcome evaluation; their longest survival reported was 36 months. This is similar to our experience where longest survival was 42 months. Conversely, Dettenborn et $\mathrm{al}^{10}$ reported 80 patients with HNCAS treated surgically (44 patients also received postoperative RT) with curative intent and 5-year OS of $54 \%$ and median OS of 64 months. Similarly, Suzuki et $\mathrm{al}^{12}$ described their experience of definitive RT as the principal curative treatment for HNCAS; a median OS survival of 31 months was attained. Nonetheless, the results of RT were compromised when palliative cases were incorporated: only $12 \%$ of patients survived more than 5 years in one study. ${ }^{14}$

Our patients were older (median age, 81 years) than those reported in the literature (median age, 63-77 years) [Table 3]. The prognostic significance of age on the outcome of HNCAS is controversial. Patel et $\mathrm{al}^{11}$ reported that patients younger than 70 years fared better with improved locoregional control and relapse-free survival than older patients. Although age is not a confirmed prognostic factor, advanced age often precludes patients from curative therapy due to concomitant chronic diseases or general debility. The elderly patients are also prone to dying of other disease as encountered in this series; four patients died of inter-current illnesses (Table 2). Nonetheless, effective systemic treatments can be well tolerated by some elderly patients with HNCAS. With taxanebased regimens, a response rate of $83 \%$ (10 out of 12 patients) was achieved and the progression-free survival was approximately 7 months. ${ }^{15}$ 
Surgery is historically the main treatment for HNCAS. The latest approach to optimal management of HNCAS is combined treatment encompassing surgery, RT, or chemotherapy. Adjuvant RT should be liberally offered to maximise the oncological outcomes following surgery. As shown in Table 3 , five of six studies support the beneficial role of $\mathrm{RT}^{4,6-8,10,11}$ Guadagnolo et $\mathrm{al}^{7}$ advocated simple resection of the gross tumour to facilitate noncomplicated reconstruction and thus expedite RT. Two-staged surgery was discouraged. The resection margin status was not critical to survival if timely adjuvant RT was administered. From their experience, the 5-year OS was $43 \%$ and 5-year disease-specific survival was $46 \%$. In a review article, Hwang et $\mathrm{al}^{16}$ also concluded that positive margin was common (64\%) but did not impair the ultimate outcome. They recommended that surgeons should not be too obsessive about removing each and every cancer cell if RT was to be pursued.

Definitive treatment with RT and/or chemotherapy has also been reported to be effective for HNCAS. ${ }^{9}$ Of 17 patients treated in that study, complete and partial responses were accomplished in none and five patients, respectively. The median OS was 26 months. Multimodality treatment in various combinations with surgery, RT, and chemotherapy has been asserted by Patel et al ${ }^{11}$ to be effective in improving locoregional control, relapse-free survival, and OS. In another study, survival (37 months) following combined therapy (RT and chemotherapy) was better than either modality alone: 23 months for RT and 15 months for chemotherapy. ${ }^{16}$ Docetaxel is the preferred agent due to its antiangiogenic and radio-sensitising effects. ${ }^{9}$ Other agents have also been successfully used and include doxorubicin, ifosfamide, bevacizumab, and interleukin-2. Systemic treatment may be used in a neoadjuvant setting, adjuvant setting, and as concurrent treatment with RT. ${ }^{8,17,18}$ Conversely, RT plus chemotherapy was not shown to have any prognostic value in a meta-analysis by Shin et al. ${ }^{19}$ Further studies should be carried out to elucidate the benefit of combined modality treatment.

Ip and $\mathrm{Lee}^{20}$ reported a smaller local series of CAS that was not confined to the head and neck. A total of seven patients were enrolled from three clinics of the Social Hygiene Service in Hong Kong. Only six patients had HNCAS. Similarly, poor prognosis was demonstrated in these patients. Our bigger series focusing on HNCAS provides a more updated and detailed strategy for the management of this rare disease in ethnic Chinese.

Our study has some limitations. First, the sample size was small as only 17 patients were included for evaluation. Nevertheless it is the largest series reported in our locality. The study spanned over 19 years (December 1997 to September
2016) and treatment has evolved over this period. Moreover, like many retrospective series, recall bias or selection bias are inherent limitations. Patient symptoms, signs, presentation duration, and criteria for treatment might not be completely accurate.

\section{Conclusion}

We present the first report of HNCAS in ethnic Chinese. The oncological outcome is far from satisfactory. A high index of suspicion is mandatory for prompt diagnosis of early disease. Adjuvant RT, as supported by evidence from the literature, is recommended following surgery that should aim at gross tumour extirpation to ensure uneventful reconstruction as well as timely implementation of RT. The benefit and role of systemic treatment in various combinations with surgery or RT require further study.

\section{Declaration}

All authors have disclosed no conflicts of interest.

\section{References}

1. Mark RJ, Poen JC, Tran LM, Fu YS, Juillard GF. Angiosarcoma. A report of 67 patients and a review of the literature. Cancer 1996;77:2400-6.

2. Perez MC, Padhya TA, Messina JL, et al. Cutaneous angiosarcoma: a single-institution experience. Ann Surg Oncol 2013;20:3391-7.

3. Sasaki R, Soejima T, Kishi K, et al. Angiosarcoma treated with radiotherapy: impact of tumor type and size on outcome. Int J Radiat Oncol Biol Phys 2002;52:1032-40.

4. Pawlik TM, Paulino AF, Mcgini CJ, et al. Cutaneous angiosarcoma of the scalp: a multidisciplinary approach. Cancer 2003;98:1716-26.

5. Chow TL, Chan TT, Chow TK, Fung SC, Lam SH. Reconstruction with submental flap for aggressive orofacial cancer. Plast Reconstr Surg 2007;120:431-6.

6. Aust MR, Olsen KD, Lewis JE, et al. Angiosarcoma of the head and neck: clinical and pathologic characteristics. Ann Otol Rhinol Laryngol 1997;106:943-51.

7. Guadagnolo BA, Zagars GK, Araujo D, Ravi V, Shellenberger TD, Sturgis EM. Outcomes after definitive treatment for cutaneous angiosarcoma of the face and scalp. Head Neck 2011;33:661-7.

8. Ogawa K, Takahashi K, Asato Y, et al. Treatment and prognosis of angiosarcoma of the scalp and face: a retrospective analysis of 48 patients. Br J Radiol 2012;85:e1127-33.

9. Miki Y, Tada T, Kamo R, et al. Single institutional experience of the treatment of angiosarcoma of the face and scalp. Br J Radiol 2013;86:20130439.

10. Dettenborn T, Wermker K, Schulze HJ, Klein M, Schwipper V, Hallermann C. Prognostic features in angiosarcoma of the head and neck: a retrospective monocenter study. J Craniomaxillofac Surg 2014;42:1623-8.

11. Patel SH, Hayden RE, Hinni ML, et al. Angiosarcoma of the scalp and face: the Mayo Clinic experience. JAMA Otolaryngol Head Neck Surg 2015;141:335-40.

12. Suzuki G, Yamazaki H, Takenaka H, et al. Definitive 
radiation therapy for angiosarcoma of the face and scalp. In Vivo 2016;30:921-6.

13. Buschmann A, Lehnhardt M, Toman N, Preiler P, Salakdeh MS, Muehlberger T. Surgical treatment of angiosarcoma of the scalp: less is more. Ann Plast Surg 2008;61:399-403.

14. Holden CA, Spittle MF, Jones EW. Angiosarcoma of the face and scalp, prognosis and treatment. Cancer 1987;59:104657.

15. Letsa I, Benson C, Al-Muderis O, Judson I. Angiosarcoma of the face and scalp: effective systemic treatment in the older population. J Geriatr Oncol 2014;5:276-80.

16. Hwang K, Kim MY, Lee SH. Recommendations for therapeutic decisions of angiosarcoma of the scalp and face. J Craniofac Surg 2015;26:e253-6.
17. Wollina U, Fuller J, Graefe T, Kaatz M, Lopatta E. Angiosarcoma of the scalp: treatment with liposomal doxorubicin and radiotherapy. J Cancer Res Clin Oncol 2001;127:396-9.

18. Yang P, Zhu Q, Jiang F. Combination therapy for scalp angiosarcoma using bevacizumab and chemotherapy: a case report and review literature. Chin J Cancer Res 2013;25:358-61.

19. Shin JY, Roh SG, Lee NH, Yang KM. Predisposing factors for poor prognosis of angiosarcoma of the scalp and face: systemic review and meta-analysis. Head neck 2017;39:3806.

20. Ip FC, Lee CK. Cutaneous angiosarcoma: a case series in Hong Kong. Hong Kong J Dermatol Venereol 2010;18:6-14. 